\title{
Social and Psychological Factors of Civic Identity Formation of an Individual
}

\section{Соціально-психологічні чинники становлення громадянської ідентичності особистості}

\section{Inha Petrovska}

Ph.D. in Technical Sciences, Assistant Professor of the Department of Psychology, Ivan Franko National University of Lviv, Lviv (Ukraine)

ORCID ID: https://orcid.org/0000-0001-7544-945X

Researcher ID: B-8482-2019

E-mail: inha.petrovska@lnu.edu.ua

\section{Інга Петровська}

Кандидат технічних наук, доцент, доцент кафедри психології, Львівський національний університет імені Івана Франка, м. Львів (Україна)

\section{ABSTRACT}

The aim of the article is the empirical substantiation of socio-psychological factors of the formation of civic identity of the personality.

The following research methods were used: survey, questionnaires for determining the level and the type of civic identity, the value orientations of the personality, the level of social frustration, social activity. The methods of mathematical-statistical analysis like one-way analysis of variance, multivariate analysis, discriminant analysis, regression analysis were applied. The empirical study involved 350 citizens of Ukraine in the age of 30-50, 119 (34\%) of whom were men, 231 (66\%) - women.

Address for correspondence, e-mail: kpnu_lab_ps@ukr.net Copyright: (C) Petrovska Inha

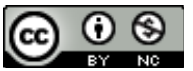

The article is licensed under CC BY-NC 4.0 International

(https://creativecommons.org/licenses/by-nc/4.0/)

(C) Petrovska Inha

DOI (article): https://doi.org/10.32626/2227-6246.2020-49.269-295 
The results of the research. It was found out that the main sociopsychological factors of civic identity formation at its different stages were: basic interpersonal needs (inclusion, affect, trust in relationships), basic beliefs (benevolence of the world, justice of the world, self-value), collectivist values of the family, civic attitudes and behavioral patterns of reference persons, orientation on sociocentric values, social integration, subjectivity of the personality, prosocial orientation and satisfaction of the needs of the person's physical and social existence in the state.

Conclusions. The formation of civic identity of personality is significantly influenced by: the subjective experience of the ability for a citizen to satisfy his / her vital needs in the state, to protect his/her interests, rights and freedom from various illegal encroachments and threats of any kind, as well as feelings, that the state is able to provide all conditions for self-realization and well-being of the person; readiness of the person to unite and to cooperate with other compatriots in order to improve the well-being of the state and its citizens, a desire to help and support others; the ability to be active, initiative, responsible, as well as conscious attitude towards the world; value orientations of the personality, which lead to interaction with the world in a prosocial way; social integration, which contributes to the formation of a sense of "We», the sense of unity and solidarity with fellow citizens; values of the family, based on strong social ties and collective performance of social duties, what causes the development of social cohesion; civic attitudes and behavioral patterns of reference of persons, on which the establishment of one or another level of respect for the state, state language and state symbols is based, the formation of basic elements (positive or negative) of awareness and acceptance / rejection of state and public values, tendency to take active or passive / indifferent civic position; the way which is based on interpersonal needs being satisfied in the childhood, which affected the formation of one or another type of a citizen; basic beliefs, which affect the formation of civic beliefs, the assessment of the person's "social value», and the importance of the man as a member of the society, as they are the basis for the implementation of acts of value choices.

Key words: civic identity; factors of formation; prosociality; subjectivity, social integration.

\section{Вступ}

Формування громадянської / державної ідентичності визначено першим завданням Концепції розвитку громадян(C) Petrovska Inha

DOI (article): https://doi.org/10.32626/2227-6246.2020-49.269-295 
ської освіти в Україні (схвалено розпорядженням Кабінету Міністрів України 3 жовтня 2018 р.). Розвиток громадянської освіти в Україні, у першу чергу, пов'язується «...3 формуванням активного та відповідального громадянина 3 високим почуттям власної гідності, стійкою громадянською позицією, готовністю до виконання громадянських обов'язків...» (Концепція, 2018: 1).

Лише за умови сформованої позитивної української громадянської ідентичності можливе «відповідальне ставлення до захисту суверенітету і територіальної цілісності України, забезпечення безпеки й усвідомлення спільності інтересів людини та держави, формування навичок, необхідних для активної участі у демократичному житті, вільному суспільстві» (Концепція, 2018: 3-4), що розглядаються як вагомі елементи громадянської освіти.

Особа зі сформованою громадянською ідентичністю здатна до громадянських ініціатив, громадянської відповідальності за суспільно-політичні процеси у державі, активної життєвої позиції, зазвичай демонструє навички конструктивної міжособистісної та суспільної взаємодії, що грунтується на взаємоповазі та співпраці, виявляє солідарність і турботу про спільне благополуччя, здатна захищати громадянські права й свободи.

Однак, без розуміння соціально-психологічних чинників становлення громадянської ідентичності особистості реалізація Концепції розвитку громадянської освіти в Україні може не дати очікуваних результатів.

Метою статті є емпіричне обґрунтування соціально-психологічних чинників становлення громадянської ідентичності особистості.

\section{Завдання статті}

1. Представити результати емпіричного дослідження чинників становлення громадянської ідентичності особистості.

(C) Petrovska Inha

DOI (article): https://doi.org/10.32626/2227-6246.2020-49.269-295 
DOI: https://doi.org/10.32626/2227-6246.2020-49

2020. випУск 49

2. Надати психологічну інтерпретацію соціально-психологічним чинникам становлення громадянської ідентичності особистості.

\section{Методи та методики дослідження}

Для визначення особливостей становлення громадянської ідентичності осіб із різним рівнем сформованості громадянської ідентичності (різних типів громадян) автором було розроблено анкету, в якій, окрім соціодемографічних показників (віку, статі, освіти тощо), респондентам було запропоновано оцінити пари протилежних тверджень, визначити, яке з двох тверджень точніше описує особу, і зафіксувати ступінь / силу вираженості кожної характеристики від 0 до 3. Твердження були подані блоками і стосувалися:

- стосунків особи окрело з батькол $і$ матір'ю (або опікунами) в дитинстві (наприклад, «я знаходився у постійному контакті та взаємодії - «не було постійного контакту та взаємодії»; «стосунки були близькі, теплі» - «стосунки були байдужі, холодні», «був наявний жорсткий контроль із боку батька (матері)» - «був відсутній контроль із боку батька (матері)», «стосунки були довірчі - недовірчі» тощо). Твердження цього блоку мали на меті з'ясувати характер задоволеності таких базисних міжособових потреб, як включеність, афект, контроль, довірчість. При формулюванні тверджень послуговувалися змістом шкал опитувальника «Базові орієнтації міжособових стосунків» В. Шутца, в адаптації А. Рукавішнікова (Рукавішніков, 1992);

- досвіду сілейних взаєлин, особливостей сілейного виховання (наприклад, «мене надмірно опікали» - «мене зовсім не опікали»; «надавали право самостійно приймати рішення» - «не надавали право самостійно приймати рішення»; «я постійно опирався волі батьків» - «я легко підкорявся волі батьків»; «батьки прислухалися до моєї точки зору» - «батьки ніколи не прислухалися до моєї точки зору» тощо);

(C) Petrovska Inha

DOI (article): https://doi.org/10.32626/2227-6246.2020-49.269-295 
- иінностей батьківськоӥ сіл’ї (наприклад, «пріоритетними цінностями батьківської сім'ї були «цінності виживання» - «пріоритетними цінностями батьківської сім’ї були «цінності самовираження»; «прийнято було підтримувати тісні родинні зв'язки» - «не прийнято було підтримувати тісні родинні зв'язки»; «приділялася велика увага розвитку критичного мислення» - «зовсім не приділялася увага розвитку критичного мислення»; «батьки вели зі мною розмови про державу (望 історію, політику тощо) - «батьки ніколи не вели зі мною розмов про державу (ії історію, політику тощо)»; «батьки завжди залучали мене до різних форм громадянської активності» - «батьки ніколи не залучали мене до різних форм громадянської активності» тощо);

- досвіду міжособової взаємодії з ровесниками (окремо у шкільні та студентські роки) (наприклад, «мої стосунки 3 однокласниками (одногрупниками) були дружніми» - «мої стосунки з однокласниками (одногрупниками) були ворожими»; «у школі (університеті / технікумі / училищі) я був аутсайдером» - «у школі (університеті / технікумі / училищі) я був лідером»; «я брав активну участь у шкільних (студентських) заходах" - «я уникав участі у шкільних (студентських) заходах»; «я не боявся відстоювати свою позицію» - «я боявся відстоювати свою позицію»; «у мене було багато інтересів у різних сферах» - «мене особливо нічого не цікавило» тощо);

- базисних переконань (наприклад, «у світі більше зла, ніж добра» - «у світі більше добра, ніж зла»; «людям можна довіряти» - «людям не можна довіряти»; «світ справедливий (кожна людина отримує те, на що заслуговує)» - «світ несправедливий (не кожна людина отримує те, на що заслуговує)»; «я вартий поваги і любові»-«я не вартий поваги і любові»; «можливо контролювати події свого життя» - «неможливо контролювати події свого життя» тощо). При формулюванні тверджень послуговувалися змістом шкал опитувальника «Шкала базових переконань» Р. Янов-Бульмана, в (C) Petrovska Inha DOI (article): https://doi.org/10.32626/2227-6246.2020-49.269-295 
адаптації М. Падун і А. Котельнікової (Падун \& Котельнікова, 2008);

- стилю життя і роботи (наприклад, «моя активність зазвичай спрямовується на соціально-корисні справи» «моя активність зазвичай спрямовується на справи, корисні лише для мене»; «я схильний уникати розв'язання складних життєвих завдань» - «я завжди намагаюся розв'язати складні життєві завдання»; «я надаю перевагу індивідуальному стилю в роботі» - «я надаю перевагу колективному стилю в роботі»; «мені вдається підтримувати дружні стосунки з колегами» - «мені не вдається підтримувати дружні стосунки з колегами»; «я повністю задоволений своєю професійною самореалізацією» - «я абсолютно не задоволений своєю професійною самореалізацією»; «маю негативний досвід звернення до установ задля реалізації й обстоювання своїх інтересів» - «маю позитивний досвід звернення до установ задля реалізації й обстоювання своїх інтересів» тощо).

Для виявлення рівня сформованості громадянської ідентичності й типу громадянина («відданий», «поміркований», «амбівалентний», «індиферентний» і «відчужений») використано авторський опитувальник «Рівень і тип громадянської ідентичності особистості» (Petrovska, 2019).

Особливості ціннісно-мотиваційної сфери досліджуваних, зокрема їх ціннісні орієнтації (саморегуляція, стимулювання, гедонізм, досягнення, влада, безпека, конформність, традиції, прихильність, самоорієнтація), визначено за тестом «Портрет цінностей» Ш. Шварца, в адаптації I. Семків (Семків, 2013), а ступінь задоволеності / незадоволеності потреб соціального існування у державі (освітою, матеріальним становищем, житлово-побутовими умовами, станом речей у суспільстві та державі, сферою послуг і побутового обслуговування, сферою медичного обслуговування, власним становищем у суспільстві, умовами професійної діяльності тощо) - за допомогою опитувальника «Рівень соціальної (c) Petrovska Inha

DOI (article): https://doi.org/10.32626/2227-6246.2020-49.269-295 
фрустрованості» Л. Вассермана (Вассерман, 2004). Також було використано методику «Шкала соціальної активності» М. Левицької, в адаптації С. Чолій (Чолій, 2010), що оцінює рівень спонтанної соціальної активності (участь в акціях протесту, підписання петицій, волонтерська праця, участь у голосуваннях під час політичних виборів, висування своєї кандидатури на посади в місцеві та державні органах влади тощо) й організаційної соціальної активності (приналежність до політичних партій, приналежність до професійних асоціацій, праця у структурах самоврядування, приналежність до громадських організацій, приналежність до виборчих комітетів, комісій тощо).

\section{Результати та дискусії}

В емпіричному дослідженні взяло участь 350 громадян (по 70 представників кожного типу: «відданих», «поміркованих», «амбівалентних», «індиферентних» і «відчужених») віком 30-50 років: 119 чоловіків (34\%), 231 жінка (66\%), 192 особи (55\%) є жителями міст, 158 осіб (45\%) - жителями сільської місцевості.

Проведений порівняльний аналіз (за допомогою однофакторного дисперсійного аналізу ANOVA) виявив статистично значущі відмінності між типами громадян (особами 3 різним рівнем сформованості громадянської ідентичності) за багатьма емпіричними показниками. 3 метою їх групування, а саме представлення достатньо великої кількості отриманих диференціюючих ознак через якомога меншу кількість найсуттєвіших характеристик, був проведений факторний аналіз методом головних компонент із Varimax-обертанням результуючої нормативної матриці факторних навантажень. На підставі критерію «кам'янистого осипу» було виокремлено 9 факторів, які загалом пояснюють 64,13\% загальної дисперсії. Решта дисперсій зумовлена випадковими впливами, які у зазначеній моделі не розглядаються. Внесок окремих факторів у загальну дисперсію склав у різних випадках

(C) Petrovska Inha

DOI (article): https://doi.org/10.32626/2227-6246.2020-49.269-295 
DOI: https://doi.org/10.32626/2227-6246.2020-49 2020. ВиПУСК 49

від 28,09\% до 2,43\% . Факторні навантаження представлено у табл. 1 .

таблиця 1

Факторна структура показників становлення громадянської ідентичності особистості

\begin{tabular}{|c|c|c|c|}
\hline $\begin{array}{c}\text { Назва } \\
\text { фактора }\end{array}$ & Показники & $\begin{array}{c}\text { Факторні } \\
\text { наванта- } \\
\text { ження }\end{array}$ & \begin{tabular}{|c} 
\% дис- \\
персії, \\
яку \\
пояснює \\
фактор \\
\end{tabular} \\
\hline 1 & 2 & 3 & 4 \\
\hline \multirow{8}{*}{$\begin{array}{l}\text { Суб’єкт- } \\
\text { ність }\end{array}$} & Соціальна активність & 0,68968 & \multirow{8}{*}{28,0873} \\
\hline & $\begin{array}{l}\text { Відстоювання власної позиції (у } \\
\text { шкільні, студентські роки) }\end{array}$ & 0,63289 & \\
\hline & $\begin{array}{l}\text { Базисне переконання щодо цін- } \\
\text { ності й значущості власного «Я» }\end{array}$ & 0,59227 & \\
\hline & $\begin{array}{l}\text { Ціннісна орієнтація «саморегу- } \\
\text { ляція (самостійність)» }\end{array}$ & 0,58027 & \\
\hline & Широка сфера інтересів & 0,57761 & \\
\hline & Інтернальність & 0,56573 & \\
\hline & $\begin{array}{l}\text { Вирішення складних життєвих } \\
\text { завдань }\end{array}$ & 0,56402 & \\
\hline & Відповідальність & 0,52755 & \\
\hline \multirow{7}{*}{$\begin{array}{l}\text { Базисні } \\
\text { міжосо- } \\
\text { бові } \\
\text { потреби }\end{array}$} & Базисна потреба афекту & 0,89008 & \multirow{7}{*}{9,3306} \\
\hline & $\begin{array}{l}\text { Довірчість у стосунках із батька- } \\
\text { ми }\end{array}$ & 0,84701 & \\
\hline & Базисна потреба включеності & 0,81782 & \\
\hline & Щасливе дитинство & 0,75022 & \\
\hline & $\begin{array}{l}\text { Батьки прислухалися до точки } \\
\text { зору дитини }\end{array}$ & 0,69988 & \\
\hline & Цікаве дитинство & 0,66019 & \\
\hline & $\begin{array}{l}\text { Цінності самовираження як } \\
\text { пріоритетні цінності батьківської } \\
\text { сім’ї }\end{array}$ & 0,50342 & \\
\hline
\end{tabular}

(C) Petrovska Inha

DOI (article): https://doi.org/10.32626/2227-6246.2020-49.269-295 
Продовження табл. 1

\begin{tabular}{|c|c|c|c|}
\hline 1 & 2 & 3 & 4 \\
\hline \multirow{5}{*}{$\begin{array}{c}\text { Соціо- } \\
\text { цент- } \\
\text { ричні } \\
\text { ціннісні } \\
\text { орієн- } \\
\text { тації }\end{array}$} & Ціннісна орієнтація «безпека» & 0,79180 & \multirow{5}{*}{5,3922} \\
\hline & $\begin{array}{l}\text { Ціннісна орієнтація «конформ- } \\
\text { ність» }\end{array}$ & 0,77414 & \\
\hline & $\begin{array}{l}\text { Ціннісна орієнтація «універса- } \\
\text { лізм» }\end{array}$ & 0,76223 & \\
\hline & $\begin{array}{l}\text { Ціннісна орієнтація «доброзич- } \\
\text { ливість» }\end{array}$ & 0,73131 & \\
\hline & Ціннісна орієнтація «традиції» & 0,58847 & \\
\hline \multirow{6}{*}{$\begin{array}{c}\text { Грома- } \\
\text { дянські } \\
\text { наста- } \\
\text { новлен- } \\
\text { ня та } \\
\text { взірці } \\
\text { поведін- } \\
\text { ки рефе- } \\
\text { рентних } \\
\text { осіб }\end{array}$} & $\begin{array}{l}\text { Участь батьків у різних громад- } \\
\text { ських організаціях }\end{array}$ & 0,77707 & \multirow{6}{*}{4,6354} \\
\hline & $\begin{array}{l}\text { Розмови з батьками про державу } \\
\text { (історію, політику тощо) }\end{array}$ & 0,66028 & \\
\hline & $\begin{array}{l}\text { Залучення дитини до різних } \\
\text { форм громадянської активності }\end{array}$ & 0,62178 & \\
\hline & $\begin{array}{l}\text { Залучення до обговорення різних } \\
\text { тем (побутових, світоглядних) }\end{array}$ & 0,58665 & \\
\hline & Розвиток критичного мислення & 0,56047 & \\
\hline & $\begin{array}{l}\text { У батьківській сім’ї було прий- } \\
\text { нято багато читати }\end{array}$ & 0,53331 & \\
\hline \multirow{5}{*}{$\begin{array}{c}\text { Соці- } \\
\text { альна } \\
\text { інтегро- } \\
\text { ваність }\end{array}$} & $\begin{array}{l}\text { Лідерство (у шкільні, студентські } \\
\text { роки) }\end{array}$ & 0,74541 & \multirow{5}{*}{4,2256} \\
\hline & $\begin{array}{l}\text { Дружні стосунки з однокласни- } \\
\text { ками }\end{array}$ & 0,69348 & \\
\hline & $\begin{array}{l}\text { Дружні стосунки з одногрупни- } \\
\text { ками }\end{array}$ & 0,62523 & \\
\hline & $\begin{array}{l}\text { Участь у колективних заходах (у } \\
\text { шкільні, студентські роки) }\end{array}$ & 0,58040 & \\
\hline & Дружні стосунки з колегами & 0,50589 & \\
\hline \multirow{3}{*}{$\begin{array}{c}\text { Колекти- } \\
\text { вістські } \\
\text { цінності } \\
\text { батьків- } \\
\text { ської } \\
\text { сім’ї }\end{array}$} & $\begin{array}{l}\text { Святкування важливих подій у } \\
\text { великому колі родичів }\end{array}$ & 0,79692 & \multirow{3}{*}{3,6219} \\
\hline & \begin{tabular}{|lcc}
$\begin{array}{l}\text { Підтримка } \\
\text { зв'язків }\end{array}$ & тісних & родинних \\
\end{tabular} & 0,72966 & \\
\hline & Допомога і турбота про інших & 0,68727 & \\
\hline
\end{tabular}

(c) Petrovska Inha 
Продовження табл. 1

\begin{tabular}{|c|c|c|c|}
\hline 1 & 2 & 3 & 4 \\
\hline \multirow{4}{*}{$\begin{array}{c}\text { Задово- } \\
\text { леність } \\
\text { потреб } \\
\text { фізично- } \\
\text { го та со- } \\
\text { ціально- } \\
\text { го існу- } \\
\text { вання у } \\
\text { державі }\end{array}$} & $\begin{array}{l}\text { Незадоволеність потреб фізич- } \\
\text { ного та соціального існування у } \\
\text { державі }\end{array}$ & $-0,75701$ & \multirow{4}{*}{3,3961} \\
\hline & $\begin{array}{l}\text { Незадоволеність соціальним ста- } \\
\text { тусом }\end{array}$ & $-0,69947$ & \\
\hline & $\begin{array}{l}\text { Задоволеність професійною само- } \\
\text { реалізацією }\end{array}$ & 0,58336 & \\
\hline & $\begin{array}{l}\text { Досвід звернення до інституцій } \\
\text { задля реалізації й обстоювання } \\
\text { своїх інтересів }\end{array}$ & 0,57987 & \\
\hline \multirow{4}{*}{$\begin{array}{c}\text { Базисні } \\
\text { переко- } \\
\text { нання }\end{array}$} & $\begin{array}{l}\text { Базисне переконання щодо спра- } \\
\text { ведливості світу }\end{array}$ & 0,68810 & \multirow{4}{*}{3,0046} \\
\hline & $\begin{array}{l}\text { Базисне переконання щодо при- } \\
\text { хильності світу }\end{array}$ & 0,68277 & \\
\hline & $\begin{array}{l}\text { Інтернальність (я сам є причиною } \\
\text { того, що відбувається зі мною) }\end{array}$ & 0,58278 & \\
\hline & $\begin{array}{l}\text { Базисне переконання щодо цін- } \\
\text { ності й значущості власного «Я» }\end{array}$ & 0,55089 & \\
\hline \multirow{2}{*}{$\begin{array}{l}\text { Просо- } \\
\text { ціальна } \\
\text { спрямо- } \\
\text { ваність }\end{array}$} & $\begin{array}{l}\text { Надання переваги колективному } \\
\text { стилю роботи }\end{array}$ & 0,70788 & \multirow{2}{*}{2,4341} \\
\hline & $\begin{array}{l}\text { Спрямованість активності на со- } \\
\text { ціально-корисні справи }\end{array}$ & 0,50115 & \\
\hline \multicolumn{3}{|c|}{$\begin{array}{c}\text { Загальний \% дисперсії, яку пояснює } \\
\text { факторна модель }\end{array}$} & 64,1278 \\
\hline
\end{tabular}

Для визначення «ваги», тобто рівня внесків цих факторів у спроможність розрізняти (дискримінувати) типи громадян, був застосований дискримінантний аналіз із покроковим методом. У якості змінної, що групує дані та на основі якої сформовано підвибірки, обрано типологію громадянської ідентичності (відданий, поміркований, амбівалентний, індиферентний, відчужений), а у якості змінних, що становлять предиктори, було обрано чинники, виявлені у (c) Petrovska Inha

DOI (article): https://doi.org/10.32626/2227-6246.2020-49.269-295 
результаті факторного аналізу. Порівняння змінних за критерієм Wilks' Lambda дало змогу визначити їх внесок у дискримінантну модель у порядку їх вагомості (табл. 2).

Усі дев'ять узагальнених чинників увійшли до дискримінантної моделі. Загальне значення лямбди Уїлкса (Wilks' Lambda) для дискримінантного аналізу з урахуванням усіх дев'яти включених змінних дорівнює 0,43482 (при $\mathrm{p}<0,0000)$, що свідчить про достатньо якісний розподіл за цими чинниками осіб із різним рівнем громадянської ідентичності. Отже, результати дискримінантного аналізу підтверджують важливість цих чинників у становленні громадянської ідентичності, зокрема того чи іншого її типу.

Із метою визначення внеску кожного чинника у становлення громадянської ідентичності було використано метод множинного регресійного аналізу. Залежною змінною обрано інтегральний показник громадянської ідентичності, а незалежними змінними - отримані у результаті факторного аналізу і підтверджені дискримінантним аналізом дев'ять узагальнених чинників. Результати регресійного аналізу представлено у табл. 3.

Коефіцієнт множинної кореляції $(\mathrm{R}=0,68 ; \mathrm{p}<0,0000)$ регресійної моделі є статистично значущим і визначає високий ступінь залежності інтегрального показника громадянської ідентичності із сукупністю наведених вище змінних. Загалом регресійна модель пояснюе $47 \%\left(\mathrm{R}^{2}=0,46893034\right)$ дисперсії залежної змінної. Варто зауважити, що визначені змінні, зважаючи на складність феномену громадянської ідентичності, не є єдиними чинниками її становлення, вони діють разом з іншими, не врахованими у цій моделі. Тим не менш, у застосованій регресійній моделі всі чинники мають додатні значення, тобто є такими, що позитивно впливають і сприяють становленню громадянської ідентичності особистості. 
ISSN 2227-6246 (Print)

ISSN 2663-6956 (Online)

ПРОБЛЕМИ СУЧАСНОЇ ПСИХОЛОГІЇ

DOI: https://doi.org/10.32626/2227-6246.2020-49 2020. виПУСК 49

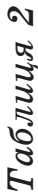

\begin{tabular}{|c|c|c|c|c|c|c|c|c|c|c|}
\hline & 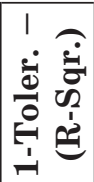 & $\begin{array}{l}\infty \\
0 \\
0 \\
0 \\
0 \\
0 \\
0\end{array}$ & $\begin{array}{l}0 \\
\infty \\
\infty \\
0 \\
0 \\
0 \\
0 \\
0\end{array}$ & $\begin{array}{l}0 \\
0 \\
0 \\
2 \\
10 \\
0 \\
0\end{array}$ & 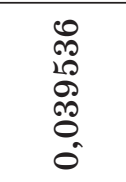 & $\begin{array}{l}\infty \\
\infty \\
10 \\
0 \\
0 \\
0 \\
0 \\
0\end{array}$ & $\begin{array}{l}-1 \\
\infty \\
10 \\
10 \\
0 \\
0 \\
0\end{array}$ & 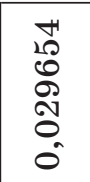 & $\begin{array}{l}0 \\
0 \\
-1 \\
\infty \\
0 \\
0 \\
0\end{array}$ & 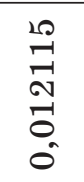 \\
\hline 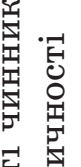 & $\frac{\dot{0}}{0}$ & 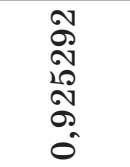 & 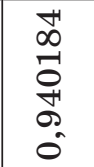 & 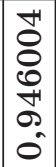 & $\begin{array}{l}+1 \\
0 \\
+1 \\
0 \\
0 \\
0\end{array}$ & 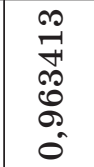 & $\begin{array}{l}0 \\
\text { ने } \\
\text { J' } \\
6 \\
\sigma \\
0 \\
0\end{array}$ & 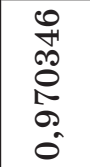 & $\begin{array}{l}+1 \\
\infty \\
\infty \\
\infty \\
\infty \\
0 \\
0\end{array}$ & $\begin{array}{l}10 \\
\infty \\
\infty \\
\infty \\
\infty \\
0 \\
0\end{array}$ \\
\hline 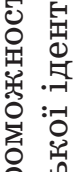 & $\frac{0}{0}$ & $\begin{array}{l}8 \\
8 \\
8 \\
8 \\
\circ \\
0 \\
0\end{array}$ & $\begin{array}{l}8 \\
8 \\
8 \\
8 \\
8 \\
0 \\
0\end{array}$ & \begin{tabular}{|l|}
8 \\
8 \\
8 \\
8 \\
8 \\
0 \\
0 \\
0
\end{tabular} & $\begin{array}{l}\text { 8 } \\
8 \\
8 \\
8 \\
0 \\
0\end{array}$ & $\begin{array}{l}\text { 8 } \\
8 \\
8 \\
8 \\
\circ \\
0\end{array}$ & \begin{tabular}{l}
$\infty$ \\
\multirow{1}{*}{} \\
8 \\
8 \\
0 \\
0
\end{tabular} & $\begin{array}{l}\text { m } \\
8 \\
8 \\
8 \\
8 \\
0 \\
0\end{array}$ & $\begin{array}{l} \\
\\
0 \\
8 \\
8 \\
0 \\
0 \\
0\end{array}$ & $\begin{array}{l}0 \\
\infty \\
\text { mo } \\
10 \\
-1 \\
0 \\
0\end{array}$ \\
\hline 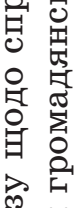 & 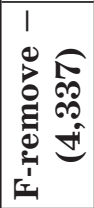 & $\begin{array}{l}4 \\
\circ \\
\infty \\
\infty \\
\infty \\
0 \\
0\end{array}$ & 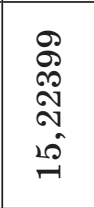 & $\begin{array}{l}N \\
N \\
\infty \\
\sim \\
\\
\tilde{r}\end{array}$ & 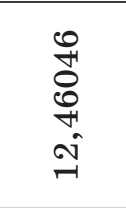 & 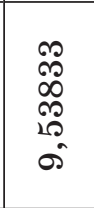 & 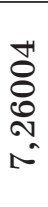 & \begin{tabular}{l}
$\overbrace{}^{+}$ \\
\multirow{1}{*}{} \\
0 \\
10 \\
0 \\
0
\end{tabular} & 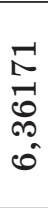 & 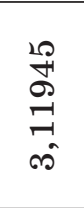 \\
\hline 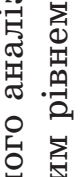 & 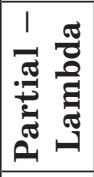 & $\begin{array}{l}10 \\
10 \\
0 \\
5 \\
0 \\
0 \\
0\end{array}$ & $\begin{array}{l}10 \\
10 \\
0 \\
0 \\
1 \\
\infty \\
0\end{array}$ & \begin{tabular}{|l|} 
\\
$\infty$ \\
20 \\
20 \\
0 \\
$\infty$ \\
0
\end{tabular} & 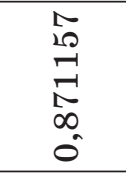 & $\begin{array}{l}\text { న } \\
\text { ஸे } \\
\infty \\
\infty \\
\infty \\
0\end{array}$ & 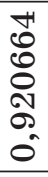 & 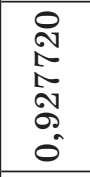 & 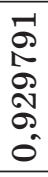 & 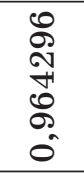 \\
\hline 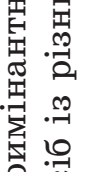 & 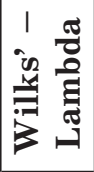 & 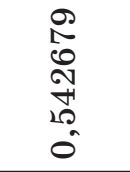 & 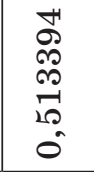 & 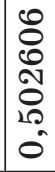 & $\begin{array}{l}\text { N } \\
\text { m. } \\
\text { S } \\
0 \\
+ \\
0 \\
0\end{array}$ & $\begin{array}{l}0 \\
10 \\
0 \\
+1 \\
\infty \\
+1 \\
0\end{array}$ & 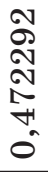 & $\begin{array}{l}8 \\
\stackrel{8}{1} \\
\infty \\
0 \\
+ \\
0 \\
0\end{array}$ & $\begin{array}{l}10 \\
10 \\
0 \\
2 \\
0 \\
4 \\
0 \\
0\end{array}$ & $\begin{array}{l}\text { ⿵ } \\
\text { जै } \\
0 \\
0 \\
10 \\
\forall \\
0 \\
0\end{array}$ \\
\hline 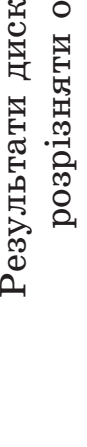 & & 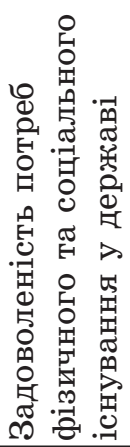 & 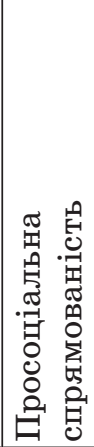 & 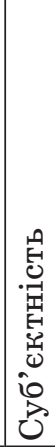 & 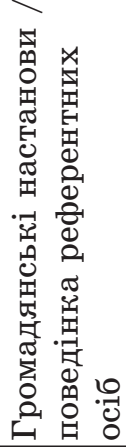 & 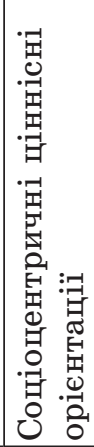 & 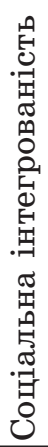 & 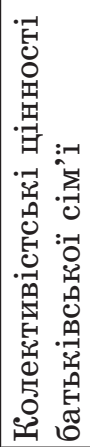 & 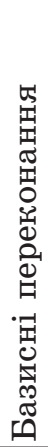 & 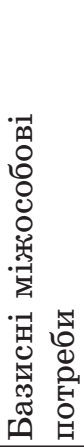 \\
\hline
\end{tabular}

(C) Petrovska Inha

DOI (article): https://doi.org/10.32626/2227-6246.2020-49.269-295 
ISSN 2227-6246 (Print)

ISSN 2663-6956 (Online)

ПРОБЛЕМИ СУЧАСНОЇ ПСИХОЛОГІЇ

DOI: https://doi.org/10.32626/2227-6246.2020-49

2020. ВИПУСК 49

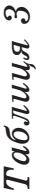

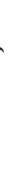

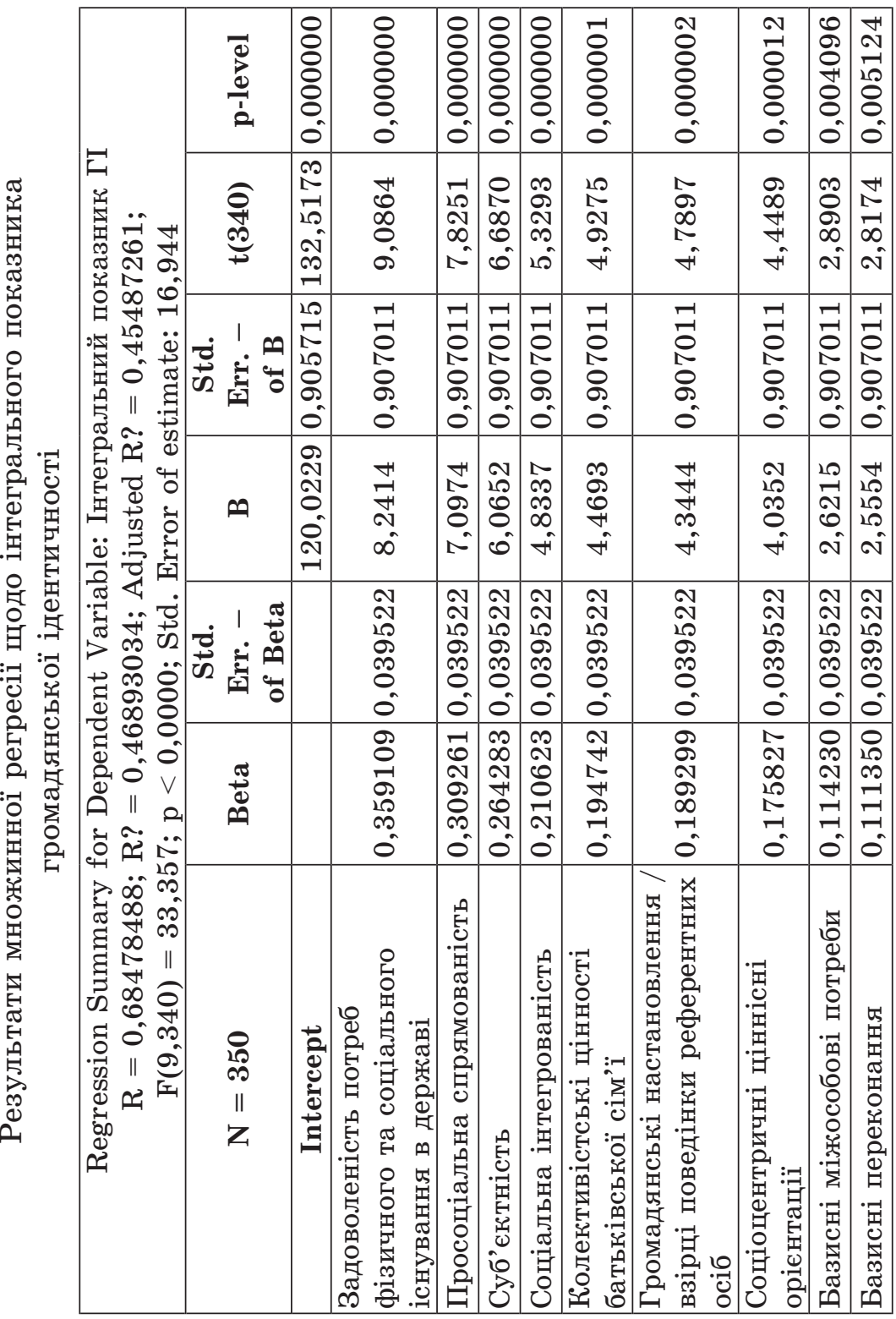

(C) Petrovska Inha

DOI (article): https://doi.org/10.32626/2227-6246.2020-49.269-295 
Отож, за результатами емпіричного дослідження виявлено, що найпотужніший внесок у становлення громадянської ідентичності (того чи іншого типу громадянина) здійснює задоволеність потреб фізичного та соціального існування в державі. Значення Beta-коефіцієнта дорівнює 0,359109, тобто вплив цього предиктора на показник громадянської ідентичності становить $36 \%$.

На зв'язок потреб людини з її політичною / громадянською ідентифікацією звертають увагу як вітчизняні, так i зарубіжні політичні психологи. Зокрема, надзвичайно важливим є задоволення потреби людини у безпеці в державі, де вона проживає, і йдеться не тільки про фізичну безпеку, але й, за словами О. Конфісахора (Конфісахор, 2004), про економічну, правову, інформаційну безпеку. Потреба особистості у безпеці, на думку Н. Хазратової (Хазратова, 2005), є однією з детермінант взаємодії особистості з державою і зумовлює прагнення впорядкованості соціального середовища, його прогнозованості та передбачуваності. Основою переживання громадянської ідентичності, за Н. Хазратовою (Хазратова, 2016: 75), є внутрішня співвіднесеність громадянина з державою, що продукує організаційний простір, у якому розгортається соціальна самореалізація кожного громадянина. На сприйняття держави, їі легітимність в очах громадян, окрім задоволеності первинних потреб (фізичного існування в державі), впливають і потреби вищого рівня (соціального існування) - потреби у професійній, духовно-культурній, особистісній самореалізації, потреби у самоповазі тощо.

Слушним є зауваження М. Фаріон і В. Ковча (Фаріон \& Ковч, 2013) про те, що в Україні, порівняно з більш розвиненими країнами, держава виявляє малу активність у задоволенні потреб свого населення. Водночас не варто нехтувати, згідно з Л. Ерхардом (Эрхард, 1991), і покладеним на кожного громадянина держави обов'язком відповідальності за свою ініціативу й активність щодо забезпечення власного існування. Проте варто зазначити, що, за даними державної (c) Petrovska Inha

DOI (article): https://doi.org/10.32626/2227-6246.2020-49.269-295 
служби статистики України, за 2018 рік дохід 14 мільйонів українців є меншим за прожитковий мінімум, і це означає, що 33,9\% громадян України живуть за межею бідності, а відтак, неспроможні забезпечити навіть власні потреби базового рівня (іжа, одяг, ліки тощо). Зростає кількість малозабезпечених і непрацездатних громадян, які перебувають у прямій залежності від матеріальної підтримки держави. Рівень оплати праці, хоч і має тенденцію до зростання, проте не відповідає реальній вартості робочої сили, особливо це стосується висококваліфікованих працівників (викладачів, науковців, медиків, інженерів тощо), які у своїй більшості не отримують того рівня доходу, який міг би забезпечити їм повноцінне задоволення потреб. Це підштовхує багатьох громадян шукати кращої долі в інших країнах. Особливе занепокоєння викликає інтелектуальна міграція, що є серйозним викликом для національної безпеки Української держави.

Значний вплив на становлення громадянської ідентичності також здійснюе просоціальна спрямованість особистості (відносний внесок її у прогнозування громадянської ідентичності складає $31 \%$ ). У цілісний конструкт, на думку Н. Корчакової (Корчакова, 2018), просоціальність вибудовується до кінця підліткового віку. А з юнацького періоду просоціальність особистості, на думку вченої, функціонує на одному з чотирьох рівнів: імпульсивно-ситуативної, інертної, зрілої просоціальності чи альтруїзму. Найвища міра продуктивності належить зрілій просоціальності, яка гармонійно поєднує два типи орієнтації: благо Іншого та цінність «Я» як соціального суб’єкта, а також передбачає виокремлення об'єктивних критеріїв доцільності просоціальних форм поведінки, розгортання рефлексивної суб'єктності, отримання особистісного задоволення від дій на благо інших. Відтак, самовизначення особистості в межах континууму «байдужість - імпульсивно-ситуативна просоціальність зріла просоціальність - альтруїзм» може зумовлювати ста-

(C) Petrovska Inha

DOI (article): https://doi.org/10.32626/2227-6246.2020-49.269-295 
новлення того чи іншого типу громадянина - «індиферентного» / «відчуженого», «амбівалентного», «поміркованого» чи «відданого» .

Варто зазначити, що оскільки просоціальність особистості формується у процесі розвитку особистості, вона зумовлюється як відповідними иінностяли батьківської сім'ї (згуртованість, тісні родинні зв'язки, допомога іншим) (вплив на показник громадянської ідентичності - 19\%), так і соціоцентричнили иінніснили орієнтаціяли (доброзичливість, конформність, традиції, універсалізм) (вплив на показник громадянської ідентичності - 18\%), тобто системою внутрішніх стандартів, ставлень особистості, що спрямовують і спонукають їі до реалізації відповідних просоціальних стратегій у взаємодії зі світом. Просоціальність особистості залежить від досвіду міжособових взаємин 3 однолітками, соціальної інтегрованості (вплив на показник громадянської ідентичності - 21\%), оскільки доведено (Twenge, Baumeister, DeWall, Ciarocco \& Bartels, 2007), що схильність до соціальної ізоляції та дистанціювання знижує ймовірність виникнення просоціальної поведінки. Дослідження (Gest, Graham-Bermann \& Hartup, 2001; Wentzel \& McNamara, 1999) виявили, що діти, які відкидаються однолітками, діють менш просоціально, ніж інші. Також доведено, що діти з меншою кількістю друзів демонструють дефіцит основних просоціальних навичок (Schonert-Reichl, 1999; Gest, Graham-Bermann \& Hartup, 2001). Соціальна й емоційна дистанційованість зумовлюється, своєю чергою, характером задоволення базисних міжособових потреб i базиснили переконанняли (відносні внески їх у прогнозування громадянської ідентичності складають по 11\%), сформованими у дитинстві. Доведено, що діти з низькою соціальною підтримкою батьків / значущих дорослих частіше трактують неоднозначні дії інших людей як агресивні чи корисливі (Anan \& Barnett, 1999), оскільки сприймають світ як ворожий, небезпечний. Діти та підлітки зі стабільних, (c) Petrovska Inha

DOI (article): https://doi.org/10.32626/2227-6246.2020-49.269-295 
згуртованих сімей мають більше шансів на дії, що приносять користь іншим людям (Romig \& Bakken, 1992), а також на ті форми поведінки, що передбачають співробітництво, допомогу, сприяння, альтруїзм, що у подальшому зумовлює формування важливих громадянських цінностей - солідарності, взаємодопомоги, співучасті, відповідальності за благополуччя своїх співвітчизників і суспільства загалом, що й реалізуються у громадянських практиках.

Вагомий вплив на становлення громадянської ідентичності здійснює суб’єктність особистості (вплив на показник громадянської ідентичності складає 26\%). Розглядаючи суб'єктність як інтегральну властивість особистості, що проявляється у здатності до самостійності, активності, ініціативності, відповідальності, самовизначення, самодетермінації, саморегуляції та самовдосконалення (Петровський, 1996), до усвідомленого та діяльного ставлення до світу і себе у ньому (Волкова, 2005); як ініціативно-творче начало особистості, що допомагає ставити цілі та намічати життєві плани, обирати стратегії життя, створювати умови для розвитку власної особистості (Анциферова, 2000); як «схильність до відтворення і творення себе у відповідних, а іноді й несприятливих умовах, що розкривається в таких поняттях, як вільний, самостійний, автономний, ініціативний, творчий, оригінальний» (Татенко, 1996: 224), звертаємо увагу на особливу важливість цієї категорії для досягнення самоідентичності, побудови цілісного образу «Я», особистісного та соціального самовизначення. Особливо актуальним питання суб'єктності постає в підлітково-юнацькому віці, коли вирішуються найважливіші завдання розвитку особистості, визначення для себе пріоритетних цінностей, життєвих намірів, розуміння власної відповідальності за їх реалізацію тощо. Суб’єктність є елементом зрілої психіки, вона виступає центральним показником особистісної зрілості людини (Татенко, 1996).

Ще одним чинником становлення громадянської ідентичності є гроладянські настановлення / взіриі поведінки (C) Petrovska Inha DOI (article): https://doi.org/10.32626/2227-6246.2020-49.269-295 
референтних осіб (вплив на показник громадянської ідентичності $-19 \%$ ). Громадянські настановлення й особистий приклад спочатку батьків, а згодом інших значущих, референтних осіб прямо чи опосередковано впливають на формування всіх компонентів громадянської ідентичності молодої людини. Аналізуючи показники, що утворили цей фактор, можна побачити, що він об’єднав два аспекти - залученість до громадянських практик батьків і / або самої дитини й увагу з боку батьків до розвитку критичного мислення дитини. Слід підкреслити той факт, що найнижчі значення за залученням дитини до обговорення різних тем (побутових, світоглядних, суспільних) та увагою батьків до розвитку критичного мислення демонструють ті досліджувані громадяни, які потрапили до «індиферентного» типу. Натомість, громадяни 3 розвинутим критичним мисленням схильні приймати більш зважені й обгрунтовані рішення (чому довіряти, а чому ні), більш осмислено та відповідально ставляться до своїх громадянських прав і обов'язків, розуміють причинно-наслідкові зв'язки різних суспільно-політичних явищ і механізмів участі у суспільному та державному житті, а відтак, краще орієнтуються у питаннях, що стосуються державного устрою, державного управління в усіх сферах суспільного життя, що зумовлює розвиток багатьох громадянських компетентностей.

\section{Висновки}

Результати емпіричного дослідження дають підстави стверджувати, що основними соціально-психологічними чинниками становлення громадянської ідентичності особистості є:

- задоволеність потреб фізичного та соціального існування у державі (суб'єктивне переживання громадянином можливості задовольнити свої життєво важливі потреби у державі, захистити свої інтереси, права і свободи від різноманітних протиправних зазіхань, будь-яких загроз (фізич(c) Petrovska Inha

DOI (article): https://doi.org/10.32626/2227-6246.2020-49.269-295 
ної, майнової, інформаційної, соціальної, економічної, політичної, екологічної, військової тощо), а також уявлення про забезпечення державою умов для самореалізації та підтримання ефективної життєдіяльності);

- просоціальна спрялованість (готовність до коопераціï, об'єднання з іншими співвітчизниками з метою покращення благоустрою держави і громадян, бажання допомагати й підтримувати інших);

- суб’єктність особистості (здатність до активності, ініціативності, відповідальності, усвідомленого та діяльного ставлення до світу і себе в ньому);

- соиіальна інтегрованість (сприяе формуванню почуття «Ми», почуття єдності та солідарності зі співгромадянами);

- колективістські иінності батьківської сіл'ї (зумовлюють розвиток соціальної згуртованості, що базується на спільних цінностях, міцних соціальних зв'язках і спільному виконанні суспільних обов'язків);

- гроладянські настановлення / взіриі поведінки референтних осіб (від значущих інших великою мірою залежить утвердження того чи іншого рівня поваги до держави, державної мови та державних символів, формування засадничих елементів (позитивних чи негативних) усвідомлення та прийняття / неприйняття державницьких і суспільних цінностей, зокрема демократії, соціальної відповідальності, справедливості, поваги до закону, толерантності, самобутності, гідності тощо; здатності до громадянських ініціатив чи обрання пасивно-байдужої громадянської позиції);

- соціоцентричні иіннісні орієнтації (спрямовують до реалізації відповідних просоціальних стратегій у взаємодії зі світом);

- базисні міжособові потреби (характер їх задоволення у дитинстві впливає на формування того чи іншого типу громадянина; схильність дорослої особи до емоційної та соціальної залученості (при позитивному досвіді інтеграції в

(C) Petrovska Inha

DOI (article): https://doi.org/10.32626/2227-6246.2020-49.269-295 
DOI: https://doi.org/10.32626/2227-6246.2020-49 2020. випУск 49 сім’ї й адекватних відносинах в емоційній сфері), здатність приймати самостійні відповідальні рішення сприяють становленню «відданого» типу громадянина, натомість соціальна дистанційованість (при недостатній інтеграції чи відкиданні дитини у родині, холодних, байдужих чи недовірливих стосунках із батьками) може сформувати у майбутньому «відчужений» тип; надмірна батьківська опіка чи повне підпорядкування дитини батьківським настановам може зумовити формування «індиферентного» типу громадянина);

- базисні переконання (виступають основою / критерієм при виконанні актів ціннісного вибору, впливають на формування громадянських переконань, на оцінку своєї «соціальної цінності»- значущості себе як члена суспільства).

Перспективи подальших розвідок полягають у розробці програм психологічного супроводу та стимулювання розвитку громадянської ідентичності на різних етапах її становлення через відповідні інститути соціалізації (сім'я, навчально-виховні та позанавчальні заклади, мас-медіа) для реалізації Концепції розвитку громадянської освіти в Україні.

\section{Література}

Анцыферова Л. И. Психологическое содержание феномена «субъект» и границы субъектно-деятельностного подхода. Проблела субъекта в психологической науке. Москва : Академический проект, 2000. C. $27-42$.

Вассерман Л. И., Иовлев Б. В., Беребин М. А. Методика для психологической диагностики уровня социальной фрустрированности и её практическое применение. Пособие для врачей и клинических психологов. Санкт-Петербург, 2004. 28 с.

Волкова Е. Н. Субъектность как деятельное отношение к самому себе, к другим людям и к миру. Мир психологии. 2005. № 3. С. 35-40.

Конфисахор А. Г. Психология власти. Санкт-Петербург : Издательский дом «Питер», 2004. 234 с.

Концепція розвитку громадянської освіти України. URL : https:// zakon.rada.gov.ua/laws/show/710-2018-p.

Корчакова Н. В. Вікова генеза просоціальності особистості: дис. ... д-ра психол. наук: 19.00.07. Київ, 2018. 476 с.

(C) Petrovska Inha

DOI (article): https://doi.org/10.32626/2227-6246.2020-49.269-295 
Микляєва А. В. Шкала самооценки личностной зрелости: опыт разработки и апробации. Современные исследования социальных проблем. 2017. Т. 8, № 2. С. 52-68.

Падун М. А., Котельникова А. В. Модификация методики исследования базисных убеждений личности Р. Янофф-Бульмана. Психологический журнал. 2008. № 4 (29). С. 98-106.

Петровский В. А. Личность в психологии. Парадигма субъектности. Ростов-на-Дону : Феникс, 1996. 440 с.

Рукавишников А. А. Опросник межличностных отношений. Ярославль : НПЦ «Психодиагностика», 1992. 47 с.

Семків I. I. Адаптація методики Ш. Шварца «Портрет цінностей» українською мовою. Практична психологія та соиіальна робота. 2013. № 1. C. $12-28$.

Татенко В. А. Психология в субъектном измерении: монография. Киев : Просвита, 1996. 404 с.

Фаріон М., Ковч В. Можливості та роль держави в задоволенні потреб суспільства за умов формування інноваційної економіки. Галицький економічний вісник. 2013. № 3 (42). С. 53-60.

Хазратова Н. В. Еволюція громадянської ідентичності в умовах пострадянської України. Психосоиіальний вимір буття особистості в сучасному суспільстві: Зб. тез доп. Міжнар. наук.-практ. конф. (м. Львів, 20-22 квіт. 2016 р.). Львів, 2016. С. 72-76.

Хазратова Н. В. Психологія відносин особистості й держави: автореф. дис. ... д-ра психол. наук: 19.00.05. Луцьк, 2005. 36 с.

Четверик-Бурчак А. Г. Опис та адаптація опитувальника «Шкала соціального благополуччя" К. Кіза. Вісник Харківського національного університету. Серія «Психологія». 2014. № 1099. С. 28-33.

Чолій С. М. Мотиваційно-ціннісний аспект соціальної активності молоді. Проблеми сучасної психологї: Збірник наукових праць Кам'янець-Подільського національного університету імені Івана Огієнка, Інституту психологї імені Г. С. Костюка НАПН України. 2010. № 10. C. 809-822.

Эрхард Л. Благосостояние для всех. Москва : Начала-Пресс, 1991. C. $230-231$.

Anan, R., \& Barnett, D. (1999). Perceived social support mediates between prior attachment and subsequent adjustment. Developmental Psychology, 35, 1210-1222.

Gest, S. D., Graham-Bermann, S. A., \& Hartup, W. W. (2001). Peer experience: Common and unique features of number of friendships, social network centrality, and sociometric status. Social Development, 10, $23-40$.

(c) Petrovska Inha

DOI (article): https://doi.org/10.32626/2227-6246.2020-49.269-295 
DOI: https://doi.org/10.32626/2227-6246.2020-49

2020. випуск 49

Petrovska, I. R. (2019). Measuring Civic Identity: Difficulties and Solution. Psychology and pedagogy in XXI century: methodological framework of the activities of psychologist and educator: collective monograph. Lviv - Toruń : Liha-Pres. P. 62-82.

Romig, C., \& Bakken, L. (1992). Intimacy development in middle adolescence: Its relationship to gender and family cohesion and adaptability. Journal of Youth and Adolescence, 21, 325-338.

Schonert-Reichl, K. A. (1999). Relations of peer acceptance, friendship adjustment, and social behavior to moral reasoning during early adolescence. Journal of Early Adolescence, 19, 249-279.

Twenge, J., Baumeister, R., DeWall, C., Ciarocco, N., \& Bartels, J. (2007). Social exclusion decreases prosocial behavior. Journal of Personality and Social Psychology, 92 (1), 56-66.

Wentzel, K. R., \& McNamara, C. C. (1999). Interpersonal relationships, emotional distress, and prosocial behavior in middle school. Journal of Early Adolescence, 19, 114-125.

\section{References}

Antsyferova, L. I. (2000). Psikhologicheskoie soderzhaniie fenomena «subiekt» i granitsy subiektno-deiatelnostnogo podkhoda [The psychological content of the phenomenon of the subject and the boundaries of the subject and activity approach]. Problema subiekta $v$ psikhologicheskoi nauke - The subject's problem in psychological science, (pp. 27-42). Moskva : Akademicheskii proiekt, 2000 [in Russian].

Vasserman, L. I., Iovlev, B. V., \& Berebin, M. A. (2004). Metodika dlia psikhologicheskoi diagnostiki urovnia sotsialnoi frustrirovannosti $i$ yeie prakticheskoie primeneniie [Methodology for the psychological diagnosis of the level of social frustration and its practical application]. Sankt-Peterburg [in Russian].

Volkova, E. N. (2005). Subiektnost kak deiatelnoie otnosheniie k samomu sebe, $\mathrm{k}$ drugim liudiam i $\mathrm{k}$ miru [Subjectivity as an active relation to oneself, to other people and to the world]. Mir psikhologii - The world of psychology, 3, 35-40 [in Russian].

Konfisakhor, A. G. (2004). Psikhologiia vlasti [The psychology of power]. Sankt-Peterburg : Izdatelskii dom «Piter» [in Russian].

Kontseptsiia rozvytku hromadianskoi osvity Ukrainy [Concept of development of civic education of Ukraine ]. (2018). Retrieved from https:// zakon.rada.gov.ua/laws/show/710-2018-p [in Ukrainian].

Korchakova, N. V. (2018). Vikova heneza prosotsialnosti osobystosti [Age genesis of prosociality of personality]. Doctor's thesis. Kyiv [in Ukrainian].

(C) Petrovska Inha

DOI (article): https://doi.org/10.32626/2227-6246.2020-49.269-295 
Mikliaieva, A. V. (2017). Shkala samootsenki lichnostnoi zrelosti: opyt razrabotki i aprobatsii [Self-esteem scale of personal maturity: experience of development and approbation]. Sovremennyie issledovaniia sotsialnykh problem - Modern researches of social problems, 8 (2), 52-68 [in Russian].

Padun, M. A., \& Kotelnikova, A. V. (2008). Modifikatsiia metodiki issledovaniia bazisnykh ubezhdenii lichnosti R. Yanoff-Bulmana [Modification of the method for the study of basic beliefs of personality of R. Yanoff-Bulman]. Psikhologicheskii zhurnal - Psychological Journal, 29 (4), 98-106 [in Russian].

Petrovskii, V. A. (1996). Lichnost v psikhologii: paradigma subiektnosti [Personality in Psychology: the Paradigm of Subjectivity]. Rostovna-Donu : Feniks [in Russian].

Rukavishnikov, A. A. (1992). Oprosnik mezhlichnostnykh otnoshenii [Questionnaire of Interpersonal Relations]. Yaroslavl : NPT «Psikhodiagnostika» [in Russian].

Semkiv, I. I. (2013). Adaptatsiia metodyky Sh. Shvartsa «Portret tsinnostei» ukrainskoiu movoiu [Adaptation of Schwartz's «Portrait Values Questionnaire» in Ukrainian]. Praktychna psykholohiia ta sotsialna robota - Practical Psychology and Social Work, 1, 12-28 [in Ukrainian].

Tatenko, V. A. (1996). Psikhologiia v subiektnom izmerenii [Psychology in the Subjective Dimension]. Kiiev : Prosvita [in Russian].

Farion, M., \& Kovch, V. (2013). Mozhlyvosti ta rol derzhavy v zadovolenni potreb suspilstva za umov formuvannia innovatsiinoi ekonomiky [Opportunities and role of the state in meeting the needs of society under conditions of formation of innovative economy]. Halytskyi ekonomichnyi visnyk - Galician Economic Bulletin, 3 (42), 53-60 [in Ukrainian].

Khazratova, N. V. (2016). Evoliutsiia hromadianskoi identychnosti v umovakh postradianskoi Ukrainy [The Evolution of Civic Identity in post-Soviet Ukraine]. Psykhosotsialnyi vymir buttia osobystosti $v$ suchasnomu suspilstvi - Psychosocial Survey of being of personality in modern society: Proceedings of the International Scientific and Practical Conference, (pp. 72-76). Lviv [in Ukrainian].

Khazratova, N. V. (2005). Psykholohiia vidnosyn osobystosti i derzhavy [Psychology of Relations between the Individual and the State]. Extended abstract of Doctor's thesis. Lutsk [in Ukrainian].

Chetveryk-Burchak, A. H. (2014). Opys ta adaptatsiia opytuvalnyka «Shkala sotsialnoho blahopoluchchia» K. Kiza [Description and Adaptation of Kiz's «Social Well-being Scale»]. Visnyk Kharkivsko-

(C) Petrovska Inha

DOI (article): https://doi.org/10.32626/2227-6246.2020-49.269-295 
DOI: https://doi.org/10.32626/2227-6246.2020-49 2020. Випуск 49

ho natsionalnoho universytetu - Bulletin of Kharkiv National University. Series "Psychology», 1099, 28-33 [in Ukrainian].

Cholii, S. M. (2010). Motyvatsiino-tsinnisnyi aspekt sotsialnoi aktyvnosti molodi [Motivational-value aspect of social activity of youth]. Problemy suchasnoi psykholohii - Problems of Modern Psychology: Collection of research papers of Kamianets-Podilskyi National Ivan Ohiienko University, G. S. Kostiuk Institute of Psychology of NAES of Ukraine, 10, 809-822 [in Ukrainian].

Erkhard, L. (1991). Blagosostoianiie dlia vsekh [Well-being for everybody]. Moskva : Nachala-Press [in Russian].

Anan, R., \& Barnett, D. (1999). Perceived social support mediates between prior attachment and subsequent adjustment. Developmental Psychology, 35, 1210-1222.

Gest, S. D., Graham-Bermann, S. A., \& Hartup, W. W. (2001). Peer experience: Common and unique features of number of friendships, social network centrality, and sociometric status. Social Development, 10, $23-40$.

Petrovska, I. R. (2019). Measuring Civic Identity: Difficulties and Solution. Psychology and pedagogy in XXI century: methodological framework of the activities of psychologist and educator, (pp. 62-82). Lviv - Toruń : Liha-Pres.

Romig, C., \& Bakken, L. (1992). Intimacy development in middle adolescence: Its relationship to gender and family cohesion and adaptability. Journal of Youth and Adolescence, 21, 325-338.

Schonert-Reichl, K. A. (1999). Relations of peer acceptance, friendship adjustment, and social behavior to moral reasoning during early adolescence. Journal of Early Adolescence, 19, 249-279.

Twenge, J., Baumeister, R., DeWall, C., Ciarocco, N., \& Bartels, J. (2007). Social exclusion decreases prosocial behavior. Journal of Personality and Social Psychology, 92 (1), 56-66.

Wentzel, K. R., \& McNamara, C. C. (1999). Interpersonal relationships, emotional distress, and prosocial behavior in middle school. Journal of Early Adolescence, 19, 114-125.

Петровська Інга. Соціально-психологічні чинники становлення громадянської ідентичності особистості

\section{АНОТАЦІЯ}

Метою статmі є емпіричне обгрунтування соціально-психологічних чинників становлення громадянської ідентичності особистості.

(C) Petrovska Inha

DOI (article): https://doi.org/10.32626/2227-6246.2020-49.269-295 
DOI: https://doi.org/10.32626/2227-6246.2020-49 2020. випУСК 49

Методи дослідження: анкетування, опитувальники на визначення рівня і типу громадянської ідентичності особистості, ціннісних орієнтацій особистості, рівня соціальної фрустрованості, соціальної активності. Застосовано такі методи математико-статистичного аналізу, як однофакторний дисперсійний аналіз, багатофакторний аналіз, дискримінантний аналіз, регресійний аналіз. У емпіричному дослідженні взяло участь 350 громадян України віком 30-50 років, із них 119 чоловіків (34\%), 231 жінка (66\%).

Результати дослідження. Виявлено, що основними соціально-психологічними чинниками громадянської ідентичності на різних етапах ії становлення є: базисні міжособові потреби (включеність, афект, довірчість у стосунках), базисні переконання (прихильність світу, справедливість світу, цінність власного «Я»), колективістські цінності батьківськоі сім'ї, громадянські настановлення / взірці поведінки референтних осіб, сочіоцентричні ціннісні орієнтації, соціальна інтегрованість, суб'єктність особистості, просоціальна спрямованість і задоволеність потреб фізичного та соціального існування у державі.

Висновок. На становлення громадянської ідентичності особистості значний вплив здійснюють: суб'єктивне переживання громадянином можливості задовольнити свої життєво важливі потреби у державі, захистити свої інтереси, права і свободи від різноманітних протиправних зазіхань і будь-яких загроз, а також уявлення про забезпечення державою умов для самореалізації та підтримання ефективної життєдіяльності; готовність особи до кооперації, об'єднання з іншими співвітчизниками з метою покращення благоустрою держави і громадян, бажання допомагати і підтримувати інших; здатність до активності, ініціативносmi, відповідальності, до усвідомленого та діяльного ставлення до світу $і$ себе в ньому; ціннісні орієнтації особи, які спрямовують до реалізації просоціальних стратегій у взаємодії зі світом; соціальна інтегрованість, що сприяє формуванню почуття "Ми», почуття єдності та солідарності зі співгромадянами; цінності батьківської сім'ї, що базуються на міцних соціальних зв'язках і спільному виконанні суспільних обов'язків і зумовлюють розвиток сочіальної згуртованості; громадянські настановлення / взірці поведінки референтних осіб, від яких значною мірою залежить утвердження того чи іншого рівня поваги до держави, державної мови та державних символів, формування засадничих елементів (позитивних чи негативних) усвідомлення та прийняття / неприйняття держав-

(C) Petrovska Inha

DOI (article): https://doi.org/10.32626/2227-6246.2020-49.269-295 
ницьких і суспільних цінностей, здатності до громадянських ініціатив чи обрання пасивно-байдужої громадянської позиції; базисні міжособові потреби, характер задоволення яких у дитинстві впливає на формування того чи іншого типу громадянина; базисні переконання, що виступають основою при виконанні актів ціннісного вибору, впливають на формування громадянських переконань, на оцінку своєї "соціальної цінності», значущості себе як члена суспільства.

Ключові слова: громадянська ідентичність, чинники становлення, просоціальність, суб'єктність, соціальна інтегрованість.

\section{Петровская Инга. Сочиально-психологические факторы становления гражданской идентичности личности}

\section{АННОТАЦИЯ}

Целью статьи является эмпирическое обоснование социально-психологических факторов становления гражданской идентичности личности.

Методы исследования: анкетирование, опросники на определение уровня и типа гражданской идентичности личности, ченностных ориентаций личности, уровня социальной фрустрированности, социальной активности. Применены такие методы математико-статистического анализа, как однофакторный дисперсионный анализ, многофакторный анализ, дискриминантный анализ, регрессионный анализ. В эмпирическом исследовании приняло участие 350 граждан Украины в возрасте 30-50 лет, из них 119 мужчин (34\%), 231 женщина (66\%).

Результаты исследования. Выявлено, чтоосновными социально-психологическими факторами гражданской идентичности на разных этапах ее становления являются: базовые межличнотные потребности (включенность, афреккт, доверительность в отношениях), базисные убеждения (доброжелательность мира, справедливости мира, ценность собственного «Я»), коллективистские ценности родительской семьи, гражданские установки / образцы поведения референтных лии, социоцентрические ценностные ориентации, социальная интегрированность, субъектность личности, просоциальная направленность и удовлетворенность потребностей физического и социального существования в государстве.

Вывод. На становление гражданской идентичности личности значительное влияние осуществляют: субъективное переживание гражда(C) Petrovska Inha

DOI (article): https://doi.org/10.32626/2227-6246.2020-49.269-295 
нином возможности удовлетворить свои жизненно важные потребности в государстве, защитить свои интересы, права и свободы от различных противоправных посягательств и угроз любого рода, а также представление об обеспечении государством условий для самореализации и поддержания эффективной жизнедеятельности; готовность личности к кооперации, объединению с другими соотечественниками с целью улучшения благоустройства государства и граждан, желание помогать и поддерживать других; способность к активности, инициативности, ответственности, к осознанному и деятельному отношению к миру и себе в нем; ценностные ориентации человека, которые направляют к реализации просоциальных стратегий во взаимодействии с миром; социальная интегрированность, которая способствует формированию чувства "Мы», чувства единства и солидарности с согражданами; ценности родительской семьи, основанные на прочных социальных связях и совместном выполнении общественных обязанностей, что обусловливает развитие сочиальной сплоченности; гражданские установки / образцы поведения референтных лиц, от которых во многом зависит утверждение того или иного уровня уважения к государству, государственному языку и государственным символам, формирование основных элементов (положительных или отрицательных) осознания и принятия / непринятия государственных и общественных иенностей, способности к гражданским инициативам или избрание пассивно-равнодушной гражданской позиции; базисные межличностные потребности, характер удовлетворения которых в детстве влияет на формирование того или иного типа гражданина; базисные убеждения, выступаюшие основой при выполнении актов ценностного выбора, которые влияют на формирование гражданских убеждений, на оценку своей «социальной ценности», значимости себя как члена общества.

Ключевые слова: гражданская идентичность, факторы становления, просоциальность, субъектность, социальная интегрированность.

Original manuscript received April 03, 2020 Revised manuscript accepted May 16, 2020 